\title{
INFLUENCE OF SILICA AND NITROGEN CONTENTS AND STRAW APPLICATION RATE ON DECOMPOSITION OF GAINES WHEAT STRAW IN SOIL
}

\author{
J. H. SMITH AND C. L. DOUGLAS \\ Snake Rituer Conservation Research Center, Kimberly, Idaho ${ }^{1}$
}

Received for gublication June 16, 1969

'Gaines' and 'Nugaines' varieties of soit white winter wheat (Triticum aestivum) yield straw ranging up to about 7 tons per acre (2). Growing row crops such as dry edible beans (Phoseolus vulgaris) or sugarbets (Beta vulgaris) following such heavy straw production poses special management problems. Straw layers that result from plowing down a large amount of straw may result in reduced bean yields (supposedly because of nitrogen immobilization), abnormal sugarbeet root growth, and tillage and water movement problems. Much of the tremendous acreage of the irrigated wheat grown in the Pacific Northwest is in rotation with sugarbeets, potatoes, beans and other crops. Therefore, straw residue management is a major problem with great economic implications.

The influence of silica content of cereal grain straws on straw decomposition has not been evaluated. Jones and Handrek (5) evaluated silica uptake and content of oats (Aveno sterilis, "Algerian") and postulated that silica covcentration in the plant is dependent upon soil solution silica concentration and water consumption. In the oat plant $\mathrm{SiO}_{2}$ concentrations ranged from $11.0 \%$ in the empty glume to $0.1 \%$ in the seed.

Much of the silica in the oat plant was reported to be opal (6). Silica in cereal grain straw is higher than in leguminous plants and Gaines wheat straw generally contains more silica than does straw from the soft white spring wheats Lemhi and Idaed (7).

The role of $\mathrm{N}$ in straw decomposition has been extensively investigated, Allison (1), and Harmsen and Van Schreven (3) prepared reviews of the extensive literature on the subject

${ }^{1}$ Contribution from the Northwest Branch, Soil and Water Conservation Research Division, Agricultural Research Service, USDA; Idaho Agricultural Experiment Station cooperating. which present the classical concepts relating $\mathrm{C}: \mathrm{N}$ ratios to plant material decomposition. Allison (1) cited references indicating that plant residues with $\mathrm{C}: \mathrm{N}$ rafios greater than 25 to 30 require external sources of $\mathrm{N}$ for most rapid decomposition. Nitrogen may be lost from plant residues with wide $C: N$ ratios aiter they have decomposed and lost enough carbon to narrow the $\mathrm{C}: \mathrm{N}$ ratio to less than sbout 30 . Because of the classical concepts that adding $N$ to straw decreases the $C: N$ ratios and accelerates straw decomposition, $N$ is frequently applied as a fertilizer for that purpose.

Experimental and practical experience indicates that the concepts are basically correct. However, the increased use of $N$ fertilizer has increased crop yields and soil fertility. James (4) reported a concentration of $650 \mathrm{lbs}$. in one field and several above $200 \mathrm{lbs}$. $\mathrm{NO}^{-}-\mathrm{N}$ per acre carried over from one crop to the next in central Washington in 1967. The bighest amount of $\mathrm{N}$ was found following two years of heavily fertilized potatoes. However; one field cropped to pumpkins and fertilized with 50 lbs. N/acre each year for the two preceding years had about 270 lbs. $\mathrm{NO}_{3}^{-}-\mathrm{N} /$ acre. A crop of wheat grown in soil with residual nitrogen as high as these cited would probably not use all the nitrogen. In such cases, the addition of $N$ may not accelerate straw decomposition. Smith (8) showed that the $\mathrm{N}$ content of straw will not influence decomposition if the soil has residual $\mathbb{N}$ or nitrification capacity to supply the needed $N$. Of course, the amount of straw applied, and the $\mathrm{N}$ content of the straw determine the amount of $\mathrm{N}$ required from outside sources to accomplish most rapid decomposition.

The objective of this study was to evaluate the infuence of silica, and $N$ contents, and straw application rate on decomposition of 
Gaines wheat straw in Portneuf silt loam soil in the laboratory.

\section{MATERTALS AND METHOD}

Gaines wheat straw from Aberdeen, Idaho, was ground to pass through an $841 \mu$ (20mesh) screen, separated into particle size fractions, and analyzed for silica and $\mathrm{N}$ con-

\section{TABLE 1}

Particle size distribution, silica, and $N$ contente of Gaines whent straw used in decomposition experiments

\begin{tabular}{ccc}
\hline $\begin{array}{c}\text { Straw particle sizes, } \\
\mu\end{array}$ & $\begin{array}{c}\text { SiO, } \\
\%\end{array}$ & $\begin{array}{c}N \\
\%\end{array}$ \\
\hline $841-500$ & 2.74 & 0.20 \\
$500-250$ & 3.02 & 0.23 \\
$250-149$ & 3.89 & 0.25 \\
$<149$ & 4.66 & 0.34 \\
\hline
\end{tabular}

tents (7). Silics and N contents increased with decreasing particle size (table 1). After analysis, the samples with particle sizes larger than $250 \mu$ were ground to pass a $250 \mu$ screen. The samples containing silica ranging from 2.74 to $4.68 \% \mathrm{SiO}_{2}$. were used in the decomposition experiments.

Samples of straw weighing either 0.5 or 1.5 $g$ were mixed with 99.5 or $98.5 \mathrm{~g}$ of Portneuf silt loam soil that had been passed through a 1-mm sereen. The soil and straw mixtures were placed in 0.5 -liter incubation bottles fitted with inlet and outlet tubes for air changing. The soil and straw mixtures were wetted with $22 \mathrm{ml}$. water containing enough $\mathrm{NH}_{4} \mathrm{NO}_{3}$ to bring the $\mathrm{N}$ content of the straw to either 0.5 or $1.75 \%$, Reference will be made hereafter to the $N$ as though it were in the straw. The flaskg containing the mixture were incubated at $27 \mathrm{C}$ for 11 weeks and

TABLE 2

Carbon dioxide evolution as influenced by silica, nitrogen and application rate of Gaines wheat straw (Statistical subclass means)

\begin{tabular}{|c|c|c|c|c|c|c|c|c|c|c|c|c|}
\hline \multirow{3}{*}{ Treatment } & \multicolumn{11}{|c|}{ Time, Weeks } & \multirow{3}{*}{ Tota] } \\
\hline & 1 & $\mathbf{2}$ & 3 & 4 & 5 & 6 & 7 & 8 & 9 & 10 & 11 & \\
\hline & \multicolumn{11}{|c|}{ Carbon, wh/weth } & \\
\hline \multicolumn{13}{|l|}{$\mathrm{SiO}_{2} \%$} \\
\hline 2.74 & 30 & 29 & 24 & 19 & 13 & 12 & 12 & 10 & 8 & 8 & 10 & 175 \\
\hline 3.02 & 30 & 24 & 20 & 17 & 13 & 11 & 11 & 8 & 8 & 8 & 10 & 160 \\
\hline 3.89 & 30 & 27 & 20 & 16 & 16 & 13 & 11 & 9 & 8 & 8 & 8 & 166 \\
\hline 4.66 & 32 & 27 & 21 & 18 & 16 & 12 & 10 & 8 & 7 & 8 & 9 & 168 \\
\hline : Significance & $\mathrm{ns}_{\mathrm{s}}$ & .10 & .10 & ns & .10 & ns & ns & ns & $\mathbf{n s}$ & $\mathbf{n s}$ & $\mathbf{n g}$. & ns \\
\hline \multicolumn{13}{|l|}{ N, \% } \\
\hline 0.5 & 29 & 29 & 20 & 15 & 12 & 8 & 9 & 7 & 6 & 7 & 8 & 150 \\
\hline 1.75 & 28 & 25 & 22 & 20 & 17 & 16 . & 13 & 10 & 9 & 9 & 10 & 179 \\
\hline Significance & $\mathrm{ns}$ & ns & .05 & .01 & .01 & 01 & 01 & .01 & .01 & .05 & 10 & .01 \\
\hline \multicolumn{13}{|l|}{ Strap, g } \\
\hline 0.5 & 28 & 28 & 18 & 10 & 6 & 4 & 4 & 2 & 2 & 3 & 7 & 112 \\
\hline 1.5 & 28 & 26 & 24 & 24 & 22 & 20 & 17 & 15 & 13 & 12 & .11 & 212 \\
\hline \multirow[t]{2}{*}{ Significanee } & ns & ns & .01 & .01 & .01 & .01 & .01 & .01 & .01 & .01 & .01 & .01 \\
\hline & \multicolumn{11}{|c|}{ Nitrogen-Straw Interactions } & \\
\hline \multicolumn{13}{|l|}{$\mathrm{N}, \%$-Straw, $\mathrm{g}^{*}$} \\
\hline 0.50 .5 & 29 & 31 & $18 \mathrm{a}$ & 11ab & $7 a b$ & $4 a$ & $6 a$ & $2 a$ & $2 a$ & $4 \mathrm{a}$ & 6 & $120 a$ \\
\hline 1.750 .5 & 28 & 24 & $18 a$ & $9 \mathrm{~B}$ & $5 \mathrm{a}$ & $4 a$ & $3 \mathrm{a}$ & $3 a$ & $2 \mathrm{a}$ & $3 \mathbf{a}$ & 7 & $106 \mathrm{a}$ \\
\hline $0.5 \quad 1.5$ & 28 & 26 & $22 \mathrm{ab}$ & $18 \mathrm{~b}$ & $16 b$ & $13 b$ & $12 \mathrm{~b}$ & $12 b$ & $10 \mathrm{~b}$ & $11 \mathrm{~b}$ & 10 & $178 \mathrm{a}$ \\
\hline 1.751 .5 & 28 & 26 & $\mathbf{2 7 b}$ & $31 \mathrm{c}$ & $29 \mathrm{c}$ & $27 \mathrm{c}$ & $22 \mathrm{c}$ & $18 \mathrm{c}$ & $16 \mathrm{~b}$ & $14 b$ & 13 & $251 b$ \\
\hline Significance & ns & ns & .05 & .01 & .01 & .01 & .01 & .01 & .01 & .01 & $\mathrm{ng}$ & .01 \\
\hline \multicolumn{13}{|l|}{ Soil Control } \\
\hline $7.5 \mathrm{mg} \mathrm{N}$ & 14 & 0 & 0 & 3 & 4 & 2 & 1 & 1 & 0 & 1 & 1 & 27 \\
\hline $20.2 \mathrm{mg} \mathrm{N}$ & 11 & 0 & 0 & 3 & 6 & 0 & 2 & 0 & 1 & 1 & 3 & 27 \\
\hline
\end{tabular}

* Numbers followed by different letters are different at the indicated significance level. 
the air in the flasks. was flushed with $\mathrm{CO}_{2-1}$ free air at weekly intervals. The $\mathrm{CO}_{2}$ was absorbed in ascarite in appropriate traps and weighed.

The treatments : were arranged in randomized blocks and replicated three times. Soil controls treated with 7.5 or $26.2 \mathrm{mg} \mathrm{N}$, equivalent to the 0.5 and $1.75 \% \cdot \mathrm{N}$ rates of the $1.5 \mathrm{~g}$ straw applications were incubated without straw simulitaneously with the other treatments. Soil nitrate was determined after. 11 weeks" incubetion by the phenoldisulfonic acid method.

\section{RESULTS AND DIBCUSBION}

Slica in the concentration range 2.74 to $4.66 \% \mathrm{SiO}_{\mathrm{s}}$ did not influence decomposition of Gaines wheat straw during most of the 11 weeks' incubation in the laboratory (table 2). During the 2nd and 3rd weeks the decomposition rate appeared to decrease slightly with increasing silica, but in the 5th week the opposite was observed. These results were significant at the $90 \%$ probability level and, because of the reversal of trend and irregularity of the data, are questionable. There were no significant interactions nor trends toward significance in decomposition because of siliea content of the straw at $2 \mathrm{~N}$ rates and 2 straw addition rates. Some silica content of straw may inhibit microbial activity and slow straw decomposition, but if there is a limiting concentration it is greater than the $4,6 \%$ maximum silica content found in the straw used in this experiment. The implication of this report is that the silica concentration. of Gaines wheat straw grown in southern Idaho will not slow straw decomposition.

The bigh straw application, represented by the $1.5 \mathrm{~g}$ in $98.5 \mathrm{~g}$ of soil, decomposed more rapidly with $1.75 \%$ than with $0.5 \% \mathrm{~N}$ during the $3 \mathrm{rd}$ to the 11th week of the ineubation (table 2). The differences in decomposition at the $1.5-\mathrm{g}$ straw addition rate because of $\mathrm{N}$ were great enough for statistically signifieant differences to be found in the overall comparisons of decomposition for weeks 3 to 11. The $0.5 \mathrm{~g}$ straw samples decomposed at essentially the same rate at both the 0.5 and $1.75 \% \mathrm{~N}$ addition rates.

For a maximum decomposition rate, low $\mathrm{N}$ straw requires additional $\mathrm{N}$ from an outside source. In the cases reported here. the soil
TABLE 3

Nitrate nitrogen in! soil following straw decomposition (stalistical subclass mears)

\begin{tabular}{|c|c|c|}
\hline \multicolumn{2}{|c|}{ Treatmeots } & \multirow{2}{*}{$\begin{array}{c}\text { NOS-N } \\
\text { in Soll } \\
\text { Ppm }\end{array}$} \\
\hline$\%$ & $\underset{\boldsymbol{B}}{\text { Straw }}$ & \\
\hline 0.5 & 0.5 & $93 \mathrm{~b}$ \\
\hline 1.75 & 0.5 & $27 ! c$ \\
\hline 0.5 & 1.5 & $4 \mathrm{a}$ \\
\hline 1.75 & 1.5 & $16 \mathrm{a}$ \\
\hline 0.5 & Both rates & $49 \mathrm{a}$ \\
\hline 1.75 & Both rates & $143 \mathrm{~b}$ \\
\hline Both rates & .0 .5 & $182 \mathrm{~b}$ \\
\hline Both rates & 1.5 & $10 \mathrm{~A}$ \\
\hline Soil control & $7.5 \mathrm{mg} \mathrm{N}$ & 196 a \\
\hline Soil control & $26.2 \mathrm{mg} \mathrm{N}$ & $366 \mathrm{~b}$ \\
\hline
\end{tabular}

- Numbers in underlined groups followed by different letters are different at the 05 significance level.

supplied enough $\mathrm{N}$ to eliminate decomposition differences when $0.5 \mathrm{~g}$ of straw was applied, but not when $1.5 \mathrm{~g}$ of straw was added. Carbon dioxide evolution was much greater from the $1.5 \mathrm{~g}$ than from the $0.5 \mathrm{~g}$ straw additions but total decomposition was about 32 and $44 \%$ of the added straw, respeotively.

Carbon dioxide evolution from the eoil controls was not compared statistically with the other treatments, and it appeared to be about the same for both $N$ treatments (table 2). The soil controls - were not subtracted from the values reported in table 2.

The nitrate eontent of the soil following 11 weeks' incubation with straw was not influeneed by different silica contents of the straw, and averaged about 96 ppm, nitrate N. However, the nitrate content of the soil was greatly influenced by the atraw application rates and the straw nitrogen contents (table 3 ). Statistical subolass means for nitrate as influenced by straw nitrogen showed a highly significant difference, with less nitrate in the soil for the 0.5 than for the $1.75 \% \mathrm{~N}$ treatments. Straw applieation rates were also aignificant, with lower nitrate being found with the $1.5-\mathrm{g}$ than the $0.5-\mathrm{g}$ straw spplication rates. The interactions between the straw application and $\mathrm{N}$ treatment were also significant. At the 
$0.5-\mathrm{g}$ straw application, the higher $\mathrm{N}$ treatment had much more nitrate than the lower $\mathbf{N}$ treatment but the presence of appreciable nitrate in both cases indicated excess nitrogen for decomposition. At the 1,5-g straw application rate, both nitrate levels were low, indicating $\mathbf{N}$ deficiency. The nitrate content of the soil control that received $26.2 \mathrm{mg} \mathrm{N}$ (corresponding to $1.75 \% \mathrm{~N}$ in straw) was $366 \mathrm{ppm}$. after ineubation. The corresponding sample treated with $0.5 \mathrm{~g}$ straw contained $271 \mathrm{ppm}$. and the sample treated with $1.5 \mathrm{~g}$ straw the soil contained 16 ppm. nitrate $N$ after incubation. Some $\mathrm{N}$ immobilization apparently occurred with the 1.5-g application even though the $1.75 \% \mathrm{~N}$ content straw should be near the theoretical equilibrium and should not immobilize additional soil $\mathrm{N}$.

Nitrogen loss may also bave occurred in the system. Caleulations of oxygen depletion indicate a maximum depletion of about $65 \%$ for the 1.5-g straw samples early in the incubation period. While this depletion level would leave $7.3 \% \quad O_{2}$ in the system, oxygen tension may have been low enough in localized areas for short duration between air flughing to allow denitrification, utilizing the nitrate as an oxygen source. This may have contributed to the low nitrate values in the 1.5 -g straw treatments with $1.75 \% \mathrm{~N}$.

\section{SUMMART}

Silica contents of Gaines wheat straw rangjng from 2.74 to $4.66 \% . \mathrm{SiO}_{2}$ did not influence decomposition of the straw. This would suggest that the silica content of the straw is not a factor in decomposition of straw normally found in the field in southern Idaho. Nitrogen contents of 0.5 and $1.75 \%$ did not influence deomposition when $0.5 \mathrm{~g}$ of straw was incubated in $99.5 \mathrm{~g}$ of soil. Straw containing $1.75 \%$ $\mathrm{N}$ decomposed faster than straw containing $0.5 \% \mathrm{~N}$ when $1.5 \mathrm{~g}$ was added to $98.5 \mathrm{~g}$ soil. With the $0.5 \mathrm{~g}$ straw treatment, the soil supplied enough $N$ to eliminate differenees in decomposition because of $\mathrm{N}$, but this was not the case when $1.5 \mathrm{~g}$ of straw was added to the soil. Nitrate remaining in the soil after 11 weeks' incubation was related to the amount of $\mathrm{N}$ in the straw and the straw application rate. When decomposition was not influenced by straw $\mathbf{N}$ content, a large amount of nitrate was found after the incubation. When $\mathrm{N}$ limited decomposition, little nitrate was found in the soil:

These findings support the accepted concepts involved in straw management. Under eertain conditions in the field when soil $\mathrm{N}$ or nitrification potential are high, fertilizer $\mathrm{N}$ applied to fairly low straw application will not accelerate decomposition. Conversely, when large straw applications are made or a large amount of straw remains from a crop on land low in residual nitrogen and low in nitrification capacity, additional nitrogen probably will hasten decomposition.

\section{REFERENCES}

(1) Allison, Franklin E. 1966 The fate of nitrogen applied to soils. Advances in Agron. 18: $210-258$.

(2) Douglas, C. L., Smith, J. H. and LeBaron, M. J. Nitrogen fertilization and irrigation of Nugaines and Lemhi wheat. Univ. of Idaho Expt. Sta. Bul, (In press).

(3) Harmsen, G. W. and VanSehreven, D. A. 1955 Mineralization of organic nitrogen in soil. Advances in Agron. $7: 299-398$.

(4) James, D. W. et al. 1968 Predicting the nitrogen fertilizer requirements of sugar beets grown in central. Washington; 1967 regerch results. Wash. Agr, Expt. Sta. Gircular $488.11 \mathrm{pp}$.

(5) Jones, I. H. P. and Fandreck, K. A. 1965 Studies of silica in the oat plant: 3. Plant and Soil $23: 79-96$.

(6) Jones, L. H. P., Milne, A. A. and Wadham, S. M. 1963 Studies of silica in the oat plant: 2. Plant and Soil 18: 358-371.

(7) Smith, J. H., Carter, D. L., Brown, M. J. and Douglas, C. L. 1968 Differences in chemical composition of plant fractions resulting from grinding and screening. Agrop. Jour. 60: 149-151.

(8) Smith, J. H. 1969 The influence of nitrogen on straw decomposition in the field and laboratory. 8th Ann. Wash. State Potato Conf. Proc. 120 pp. 